Turan, E.D., Kurt, E. ve Arslan, N. (2016) Mini Kumbara Dergisi'nin popüler bilim kaynakları kapsamında biçim ve içerik bakımından incelenmesi. Ana Dili Eğitimi Dergisi, 4(3), 326-336.

$\begin{gathered}\text { Ana Dili Eğitimi Dergisi } \\ \text { Journal of Mother Tongue Education } \\ \text { www.anadiliegitimi.com }\end{gathered}$
Geliş/Received: $08.04 .2016 \quad$ Kabul/Accepted:08.06.2016

\title{
Mini Kumbara Dergisi'nin Popüler Bilim Kaynakları Kapsamında Biçim ve İçerik Bakımından İncelenmesi
}

Emine Damla TURAN*

Elif $K U R T^{* *}$

Nazmi ARSLAN ${ }^{* * *}$

\begin{abstract}
Öz
Popüler bilim, toplumun her kesimi tarafından rahatça anlaşılabilecek bir dille ve şekilde yapılan bir bilim olarak tanımlanır. Günümüzde popüler bilim çerçevesinde çocuklara yönelik birçok yayın bulunmaktadır. Bu yayınlar arasında çocuk dergileri önemli yer tutmaktadır. Çocuk dergileri çocuk edebiyatı ürünleri arasında süreli yayınlar kategorisindedir. Bu çalışmanın amacı, okul öncesi çocuklar için hazırlanan ve İş Bankası tarafından ücretsiz olarak dağıtılan Mini Kumbara Dergisi'ni popüler bilim çerçevesinde biçimsel ve içeriksel olarak inceleyip değerlendirmektir. Araştırmada doküman incelemesi yöntemi kullanılmıştır. Araştırmanın veri kaynağını İş Bankası Kültür Yayınları'nın okul öncesine yönelik çıkardığı "Mini Kumbara Dergisi" oluşturmaktadır. Bu araştırmada Mini Kumbara Dergisi'nin ilk dört yılında yayınlanan 16 sayısı incelenmiştir Çalışmanın verileri, ilgili literatür incelenerek çocuk edebiyatı eserlerinde bulunması gereken biçimsel ve içeriksel özellikler çerçevesinde oluşturulan "Popüler Bilim Çerçevesindeki Çocuk Yayınlarını Değerlendirme Formu" ile toplanmıştır. Veriler "betimsel analiz" yöntemiyle analiz edilmiştir. Araştırma bulguları tablolar halinde sunulmuştur. Araştırma sonuçlarına göre derginin biçimsel ve içeriksel özellikler açısından büyük ölçüde yeterli olduğu sonucuna ulaşılmıştır.
\end{abstract}

Anahtar Kelimeler: Popüler bilim, çocuk dergisi, biçimsel özellikler, içeriksel özellikler.

\section{Form and Content Analysis of Mini Kumbara Magazine as Part of Popular Science Resources}

\footnotetext{
Abstract

Popular science is defined as a science that is done in a language and manner easily understandable by all segments of society. Today there are many publications for children within the framework of popular science. Children's magazines hold an important place among these publications. Children's magazines are included in the periodicals category of children's literature. The aim of this study is to examine and evaluate Mini Kumbara Magazine, which is prepared for preschool children and distributed for free by Isbank (Türkiye Iş Bankası), in terms of formal and contextual features within the framework of popular science. The study is based on document analysis method. The data source of the study is "Mini Kumbara Magazine" published for preschool children by IsBank Cultural Publications. The study examined 16 issues of Mini Kumbara Magazine published in the first four years. Data was collected by an "Evaluation Form for Children Publications within the Popular Science Framework" designed taking into consideration the formal and contextual features that should be included in children's literary works based on the literature review. Data

*Arş. Gör., Karadeniz Teknik Üniversitesi Fatih Eğitim Fakültesi Türkçe Eğitimi Bölümü, Trabzon, e-posta: dkocaturk@ktu.edu.tr

** Doktora Öğrencisi, Karadeniz Teknik Üniversitesi Fatih Eğitim Fakültesi Türkçe Eğitimi Bölümü, Trabzon, e-posta: elifkurt07@hotmail.com

Ar** Ars. Gör., Karadeniz Teknik Üniversitesi Fatih Eğitim Fakültesi Türkçe Eğitimi Bölümü, Trabzon, e-posta: nazmiarslan@ktu.edu.tr
} 
was analyzed by descriptive analysis method. The research findings were presented in tables. The study revealed that the magazine was adequate to a considerable extent in terms of formal and contextual features.

Key Words: Popular science, children's magazines, formal features, contextual features.

\section{Giriş}

Popüler bilim, toplumun her kesimi tarafından rahatça anlaşılabilecek bir şekilde ve dilde yapılan bir bilim olarak tanımlanır. Popüler bilim yazıları; bilimin toplum ile paylaşılmasında, bilim ile toplum arasında bağ kurulmasında, halkın bilimden haberdar olmasında çok önemli bir yere sahiptir. “iyi bir popüler bilim yazısı, bilgileri steril bir ortam içinde üretilmiş ve sorgulanamaz gerçekler olarak aktarmaz"(URL-1). Tüm topluma hitap eden popüler bilim yazıları çocuklara yönelik de olmalıdır. Günümüzde teknoloji eksenli buluşların bir gereği olarak bilimsel buluşları ve doğa olaylarını anlatan yazılar, içerikleri itibariyle çocukların merak duygularını harekete geçiren, onların hem zevkle vakit geçirmelerine hem de bilgi sahibi olmalarına vesile olan bir tür olarak kabul edilmektedir (Demirel, Çeçen, Seven, Tozlu ve Uludağ; 2011: 329).

Günümüzde popüler bilim çerçevesinde çocuklara yönelik birçok yazı kaleme alınmaktadır. Çocukların ilgi ve ihtiyaçlarına yönelik olan bu yazılar çeşitlilik göstermektedir.

"Çocuklar içinde yaşadıkları doğal çevreyi tanımak, bu çevrede yaşayan hayvan ve bitki gibi canlı varlıklar ile türlü cansız varlıkların özelliklerini öğrenmek isterler. Rüzgâr, yağmur, mevsim değişimi, çiçeklerin ve ağaçların büyümesi, kuşların göçmesi gibi sayısız doğa olaylarına karşı daha pek erken yaşlarda ilgi duymaya başlarlar. Çocuklar ayrıca yeni buluşlara, fen alanındaki son gelişmelere ve bu buluşların ve gelişmelerin ürünü olan makinelere, ulaşım araçlarına, iletişim gereçlerine karşı da yakın ilgi gösterirler. Çocukların bu konulardaki ilgi ve meraklarını gidermek amacıyla birçok eser yayınlanmış bulunmaktadır" (Oğuzkan, 2010: 228).

Farkıı kurumlar ya da kişiler tarafından çeşitli şekillerde yayınlanan eserlerden biri de çocuk dergileridir. Çocuk dergileri çocuk edebiyatı ürünleri arasında süreli yayınlar kategorisindedir. "Çocuk dergilerinin en önemli özellikleri, bir hafta, on beş gün veya bir aylık sürelerle çocukları ilgilendiren güncel haber, olay veya bilimsel gelişmeleri yansıtan iletişim araçları olmalarıdır" (Yılar ve Celepoğlu, 2007: 47). Bu yayınlar "öğrencilerde olayları izleme ve değerlendirme yeteneklerini geliştirir. Ders konuları ile güncel konular arasında ilgi kurmaya yarar. Çevre ile okul arasındaki uzaklığı giderir. Toplumsal hayat ve okul hayatı arasında köprü kurmaya zemin hazırlar. Güncel olayları ve sanat etkinliklerini izleme ve yorum yapma alışkanlığı kazandırır" (Şimşek, 2002: 20). Ayrıca "dergilerde yayımlanan öğretici ve eğlendirici yazılar, masallar, hikâye ve romanlar, fıkralar, bilmeceler, resimler, fotoğraflar ve karikatürler çocukların okuma alanındaki bireysel ihtiyaç ve ilgilerini doyurucu biçimde karşılayabilir (Oğuzkan, 2010: 345).

Yılar ve Celepoğlu'na (2007: 47) göre çocuk dergilerinin yararları şu şekilde sıralanabilir: 
- $\quad$ Çocuklar, dergilerdeki ilgi çekici resimler sayesinde hem hoşça vakit geçirir hem de okuma, düşünme faaliyetlerini istekli yaparlar. Bu da onların okuma zevk ve alışkanlığını geliştirmelerine yardımcı olur.

- Çocuğun hayatı tanımasına ve hayata hazırlanmasına destek olur. Çocuğa yaşama sevgisi verir ve ruhuna canlılık katar.

- $\quad$ Çocuğun Türkçeyi etkili ve güzel bir şekilde kullanmasına yardımcı olur.

- $\quad$ Çocuk, güncel olayları izleyerek toplumsal bilinç kazanmaya başlar.

- Yazmaya, çizmeye, yorum yapmaya yardımcı olarak çocuğun yaratıcı etkinliklerde bulunmasına büyük katkı sağlar.

- C Çocuğun kelime dağarcığının artmasına yardımcı olur.

- Çocukların kendi yaş grupları arasında bir bilgi veya konuşma konusu aracı olarak sosyal yönden de geliş̧melerine yardımcı olur.

- $\quad$ Çocukların farklı konulara ilgi duymasını sağlayarak merak duygusunu kamçılar, onları sanata ve edebiyata yaklaştırır.

Çocuklara yönelik olarak hazırlanan kaynakların çocukların gelişiminde büyük etkileri vardır. Günümüzdeki teknolojik gelişmelere paralel olarak bilimsel buluşları ve doğa olaylarını anlatan yazılar çocukların dikkatini çekmesi ve onları geleceğe hazırlaması açısından önem taşımaktadır. Demirel ve diğerleri, (2011) çocukların, seviyelerine uygun olarak kaleme alınan bu tür yazılar ile hem gözlem becerilerini geliştirebildiklerini hem önce yakın sonra uzak çevrelerini tanıyabildiklerini hem de okudukları eserlerdeki teorik bilgiler ile gerçek hayatta karşılaştıkları olaylar arasında ilişki kurarak sentez yapabildiklerini belirtirler. Ayrıca bu durumun aynı zamanda onların eleştirel düşünebilmelerine ve yaratıı etkinliklerde bulunabilmelerine imkân sağladığını ifade ederler.

Çocuk dergileri çocuğun gelişimi açısından büyük önem taşımaktadır. "Işslevleri göz önünde bulundurulursa ne denli ciddi bir iş olduğu görülen süreli çocuk yayıncılığı uzmanlık gerektiren bir sektördür. Çocuk psikolojisi, çocuğun bilişsel ve dil gelişimi dikkate alınarak yapılan yayıncılık başarıya ulaşabilirse çocuğun gelişimine katkıda bulunabilir. Bu yüzden süreli çocuk yayınlarının yazar kadrosu ve eğitimci kimliği de önemlidir" (Ungan ve Yiğit, 2014: 185).

Çocuklara yönelik yayınlarda bulunması gereken birtakım özellikler vardır. Çocuk dergilerinin de bu özellikleri taşıması gerekir. Bu özellikler genel olarak "biçimsel" ve "içeriksel" olmak üzere iki ana başlık altında toplanır. Güleryüz (2003), Şimşek (2002) ve Oğuzkan (2010) tarafından belirlenen biçimsel özellikler resimleme; kapak, boyut, cilt; sayfa ve yazı tasarımı; metin tasarımı; içeriksel özellikler konu, tema, ana fikir, plan, dil ve anlatım temaları altında gruplandırılabilir. Çocuk yayınlarında bulunması gereken bu özelliklere çocuklara yönelik olan popüler bilim kaynakları da sahip olmalıdır. 
Konu ile ilgili literatür incelendiğinde çocuk kitapları ve çocuk dergileriyle ilgili çalışmalar görülmektedir. Çocuk kitapları ile ilgili Demircan’ın (2006) “TÜBiTAK Çocuk Kitaplığı Dizisindeki Kitapların Dış Yapısal Ve İç Yapısal Olarak İncelenmesi"; Gönen, Katrancı, Uygun ve Uçuş'un (2011) “ilköğretim Birinci Kademe Öğrencilerine Yönelik Çocuk Kitaplarının İçerik, Resimleme ve Fiziksel Özellikleri Açısından İncelenmesi" adlı çalışmalar bulunmaktadır. Çocuk dergileri ile ilgili olarak ise Demiryürek'in (2012) “TRT Çocuk Dergisi'nin Yapısal Özellikleri Bakımından Değerlendirilmesi”; Ulutaş ve Çaydaş'ın (2013) "ileri Yavrutürk Dergisinin Teknoloji Açısından Değerlendirilmesi”; Güran Yiğitbaşı'nın (2014) “Türkiye'de Çocuk Dergiciliği: TRT Çocuk Dergisi Örneği” adlı çalışmalarına rastlanmaktadır.

Bu çalışmanın amacı, okul öncesi çocuklar için hazırlanan ve iş Bankası tarafından ücretsiz olarak dağıtılan Mini Kumbara Dergisi'ni popüler bilim çerçevesinde biçimsel ve içeriksel olarak inceleyip değerlendirmektir. Araştırma sonuçlarının, ileride yapılacak diğer çalışmalara da kaynaklık edeceği düşünülmektedir.

\section{Yöntem}

Araştırmada doküman incelemesi yöntemi kullanılmıştır. "Doküman incelemesi, araştırılması hedeflenen olgu veya olgular hakkında bilgi içeren yazılı materyallerin analizini kapsar" (Yıldırım ve Şimşek, 2005: 188). Hem nitel hem nicel araştırmalarda kullanılan bu yöntemde yazılı ve görsel materyaller incelenebilir. "Yazılı kaynaklar kitaplar, dergiler, fermanlar, anılar, makaleler, layihalar, romanlar, öyküler, şiirler, yazıtlar; görsel malzemeler ise resimler, slaytlar, filmler, anıtlar, giyim-kuşam, araç-gereçler, pullar, flamalar vb. olabilir" (Sönmez ve Alacapınar, 2011: 83). "Doküman metodu, resmi ya da özel kayıtların toplanması, sistematik olarak incelenmesi ve değerlendirilmesinde yararlanılan bir metottur" (Ekiz, 2003: 70).

\section{Veri Kaynağı}

Araştırmanın veri kaynağını, İ̧̧ Bankası Kültür Yayınları'nın okul öncesine yönelik çıkardığı “Mini Kumbara Dergisi" oluşturmaktadır. 2011 yılında yayın hayatına başlayan dergi üç ayda bir yayımlanmaktadır. Ayrıca dergi ücretsiz olarak dağıtılmakta ve sanal ortamda da yer almaktadır. Araştırma kapsamında 2011 İlkbahar - 2015 Ilkbahar dönemi arasında çıkarılan toplam 16 sayı Mini Kumbara Dergi'si incelenmiştir.

\section{Veri Toplama Aracı}

Çalışmada veri toplama aracı olarak araştırmacılar tarafından geliştirilen "Popüler Bilim Çerçevesindeki Çocuk Yayınlarını Değerlendirme Formu" kullanılmıştır. Bu form popüler bilim kaynaklarının sahip olduğu özellikleri değerlendirmeye yöneliktir. Güleryüz (2003), Şimşek (2002) ve Oğuzkan (2010) tarafından belirlenen biçimsel özellikler resimleme; kapak, boyut, cilt; sayfa ve yazı 
tasarımı; metin tasarımı; içeriksel özellikler konu, tema, ana fikir, plan, dil ve anlatım temaları altında gruplandııımıştır. Bunlara ek olarak araştırma amacına uygun, popüler bilim kaynaklarında bulunması gereken "bilimsellik" teması eklenmiştir.

Formda bu kaynakların içeriksel özelliklerine yönelik 36 madde 4 tema, biçimsel özelliklerine yönelik 14 madde 4 tema olmak üzere toplam 50 madde 8 tema bulunmaktadır. Formda bulunan içeriksel özelliklere ait maddelere örnek olarak: "Dil ve üslup yeni kavram ve kelimeleri öğretici niteliktedir." ve "Konular, öğrencinin bilimsel farkındalığını arttırmaya yöneliktir." Verilebilir. Biçimsel özelliklere ait maddelerden bazıları ise şunlardır: "Görsellerde yer alan araç-gereçler bilimsel bilgilerle tutarlıdır." ve "Cümlelerin uzunluğu öğrencilerin öğrenim kademeleri ile uyumludur." Formda her madde için "tamamen, genellikle, kısmen ve hiç" olmak üzere dört farklı değerlendirme ölçütü bulunmaktadır. Form, ilgili literatür taranarak ve farklı alanlardaki uzmanlardan görüş alınarak oluşturulmuştur.

\section{Veri Toplama Süreci}

Araştırma kapsamında değerlendirilen Mini Kumbara Dergisi'nin ilk 4 yılına ait 16 sayısı incelenmiştir. 3 araştırmacı tarafından her sayı için ayrı ayrı form doldurulmuştur. Daha sonra araştırmacılar kendi doldurdukları formları karşılaştırarak her sayı için tek bir form oluşturmuşlardır. Bu formlar 3 araştırmacı tarafından karşılaştırılıp birleştirilerek araştırmacılar arası tutarlılık sağlanmıştır. Son aşamada 16 formdan elde edilen veriler, frekans ve yüzdeleri alınarak tablolar halinde gösterilmiştir.

\section{Verilerin Analizi}

Veri analizi sürecinde "betimsel analiz" yaklaşımı kullanılmıştır. "Bu yaklaşımda, elde edilen veriler, daha önceden belirlenen temalara göre özetlenir ve yorumlanır. Bu tür analizde amaç, elde edilen bulguları düzenlenmiş ve yorumlanmış bir biçimde okuyucuya sunmaktır. Bu amaçla elde edilen veriler, önce sistematik ve açık bir şekilde betimlenir. Daha sonra yapılan bu betimlemeler açıklanır, yorumlanır ve birtakım sonuçlara ulaşılır (Yıldırım ve Şimşek, 2005:224). Bu doğrultuda yapılan analiz sonucunda elde edilen veriler tablolar halinde sunulmuş ve tablolardaki veriler dergilerdeki ifadelerle desteklenmiştir.

\section{Bulgular ve Yorum}

Araştırma sonucu elde edilen veriler tablolar halinde sunulmuştur.

Tablo 1. Mini Kumbara Dergisi'nin biçimsel özelliklerine ait frekans ve yüzde analizi

\begin{tabular}{lllllllllll}
\hline \multirow{2}{*}{ Temalar } & \multicolumn{2}{c}{ Tamamen } & \multicolumn{2}{c}{ Genellikle } & \multicolumn{2}{c}{ Kısmen } & \multicolumn{2}{c}{ Hiç } & \multicolumn{2}{c}{ Toplam } \\
& $\mathrm{f}$ & $\%$ & $\mathrm{f}$ & $\%$ & $\mathrm{f}$ & $\%$ & $\mathrm{f}$ & $\%$ & $\mathrm{f}$ & $\%$ \\
\hline Resimleme & 11,4 & 71,4 & 1,86 & 11,6 & 2,57 & 16,1 & 0,14 & 0,89 & 16 & 100 \\
Kapak, Boyut, & 5,33 & 33,3 & - & - & 10,67 & 66,67 & - & - & 16 & 100 \\
Cilt & & & & & & & & & & \\
\hline
\end{tabular}




\begin{tabular}{lllllllllll}
\hline $\begin{array}{l}\text { Sayfa ve Yazı } \\
\text { Tasarımı }\end{array}$ & 14,5 & 90,63 & 0,5 & 3,13 & 1 & 6,25 & - & - & 16 & 100 \\
Metin Tasarımı & 13,5 & 84,38 & 0,5 & 3,13 & 2 & 12,5 & - & - & 16 & 100 \\
\hline
\end{tabular}

Mini Kumbara Dergisi biçimsel özellikler açısından incelendiğinde metinlerde kullanılan görsellerin metnin içeriği ile uyumlu, öğrencinin ilgisini çekecek nitelikte ve bilişsel gelişim düzeyine uygun olduğu görülmektedir. Metinlerde kullanılan resimler, çizimler ve fotoğrafların kısmen de olsa gerçeğe yakın olduğu söylenebilir. Örneğin; 1. sayıda sayfa 20 ile 26 arasındaki güvercin çizimleri gerçeğe uygun değildir. 3. sayıda aslan çizimi, 9. sayıda "Deniz'in Hayali” öyküsünün resimleri de gerçeğe yakın değildir. 13. sayının 26. sayfasında bulunan "Tüytop Ormanda" öyküsünde kullanılan resimlerin renk tonları uygun değildir. İncelenen derginin hacim ve ağırlık bakımından kullanışlı olduğu söylenebilir; ancak derginin basımında kaliteli malzeme kullanılmadığı görülmektedir. Bu durumun, derginin ücretsiz dağıtılmasından kaynaklandığı düşünülmektedir.

Metinlerin oluşturulmasında kullanılan yazı karakteri ve büyüklüğünün, cümlelerin uzunluğunun öğrencinin seviyesine uygun olduğu elde edilen bulgular arasındadır. Derginin basımında kullanılan renklerin metinler ve görseller açısından uyumlu olduğu, sayfaların görsel tasarım ilkelerine uygun olduğu ve sayfa yapısını algılamayı kolaylaştıracak nitelikte olduğu görülmektedir. Örneğin, bütün dergilerde resimler, derginin çıkarıldığı mevsime göre tasarlanmıştır. Mevsimlere göre renk seçimi yapılmıştır; özellikle sonbahar sayılarında sarı ve kahverengi tonlarının kullanım, içerik ile renk uyumları açısından çok başarııdır.

İncelenen derginin kapağı kısmen sağlam ve dikkat çekicidir. Dergide seçilen konuların öğrencileri daha fazla araştırma yapmaya yönelttiği elde edilen veriler arasında yer almaktadır. Örneğin; 3. sayıda 21. sayfada "Kar yağdığında bir büyüteç alın ve dışarı çıkıp kar tanelerini inceleyin. Doğanın bu eşsiz güzellikteki minik yapıları sizi çok etkileyecek..." ifadesi ile çocuklar araştırma yapmaya yönlendirilmektedir.

İş Bankası Kültür Yayınları tarafından çıkarılan Mini Kumbara Dergisi'nin içeriksel özelliklerine ait bilgiler Tablo 2'de gösterilmiştir.

Tablo 2. Mini Kumbara Dergisi'nin Içeriksel Özelliklerine Ait Frekans ve Yüzde Analizi

\begin{tabular}{llllllllllll}
\hline \multirow{2}{*}{ Temalar } & \multicolumn{2}{c}{ Tamamen } & \multicolumn{2}{c}{ Genellikle } & \multicolumn{2}{c}{ Kısmen } & \multicolumn{3}{c}{ Hiç } & \multicolumn{2}{c}{ Toplam } \\
& $\mathrm{f}$ & $\%$ & $\mathrm{f}$ & $\%$ & $\mathrm{f}$ & $\%$ & $\mathrm{f}$ & $\%$ & $\mathrm{f}$ & $\%$ \\
\hline $\begin{array}{l}\text { Konu, Tema, Ana } \\
\text { Fikir }\end{array}$ & 11 & 68,75 & 3,08 & 19,28 & 1,75 & 10,94 & 0,17 & 1,04 & 16 & 100 \\
Plan & & & & & & & & & & & \\
Dil ve Anlatım & 11 & 68,75 & 4 & 25 & 1 & 6,25 & - & - & 16 & 100 \\
Bilimsellik & 12,64 & 78,98 & 2,45 & 15,34 & 0,91 & 5,68 & - & - & 16 & 100 \\
& 14,33 & 89,59 & 1,67 & 10,42 & - & - & - & - & 16 & 100 \\
\hline
\end{tabular}


Elde edilen veriler incelendiğinde içeriğin toplumsal ve kültürel konulara genel olarak dikkat çektiği, işlenen konuların öğrencilerin seviyesine uygun olduğu ve gelecekteki ihtiyaçlarına cevap verir nitelikte olduğu söylenebilir. Örneğin; bahar aylarında çıkarılan 8., 12. ve 16. sayılarda çocuklar için olan "23 Nisan Ulusal Egemenlik ve Çocuk Bayramı" ile ilgili bilgi verilmiştir. Ayrıca elde edilen veriler, ele alınan konuların ilgi çekici ve gerçek yaşam temelli olduğunu göstermektedir. Örneğin; bütün sayılar çıkarılıkları ayları kapsayan mevsimlere yönelik doğa olaylarını ve değişimleri çeşitli yönleri ile ele almaktadır. Bu doğrultuda bahar aylarında çıkartılan 1. sayıda baharın gelmesi teması işlenmiştir. Buna ek olarak dergide yer verilen konuların öğrencilere yeni ve farklı deneyimler kazandırdığı; amaçların öğrencilerin imkânları ile gerçekleşebilecek düzeyde olduğu tespit edilmiştir. Her sayıda bulunan "Bilimsel Gözlem" bölümünde çocuklar farklı deneyimlere yönlendirilmektedir. Ayrıca bu gözlemler sırasında bazı deneylere yer verilmekte ve bu deneyler basit malzemeler ile yapılabilmektedir. Meselâ; 12. sayıda gökkuşağı ile ilgili bir deneye yer verilmiştir. Bu deney için gereken malzemeler "Gün ışığı, bir su bardağı su, masa, dosya kâğıdı, renkli kalemler" olarak verilmiştir. Ayrıca 16. sayı hariç her sayıda kitap oluşturma bölümü bulunmaktadır. Bu bölümde "Kitabı yapmak için: 1-Kırmızı çizgilerden kesin. Üç ayrı parçanız olacak. 2-Her parçayı mavi çizgilerden katlayın. 3-Sıra numaraları 1'den 10'a kadar olacak şekilde parçaları iç içe yerleştirin. 4-Düzgünce yerleştirdikten sonra, kitabınızı sırtından zımbalayın. 5-Çocuğunuzun adını kitabın kapağına yazın." yönergeleri ile çocuklar kendi kitaplarına sahip olabilmektedir.

Dergiler genel olarak değerlendirildiğinde öğrenme intiyaçlarını gidermekte ve öğrenmeyi teşvik etmektedir; fakat öğrencileri üst düzey düşünme becerilerini geliştirmeye yöneltmemektedir. Bu durum derginin hedef kitlesi düşünüldüğünde olumsuz bir durum arz etmemektedir. Araştırmada incelenen dergilerde dil ve üslubun öğrencinin seviyesine uygun olduğu ve yeni kavram ile kelimeleri öğretici; ayrıca dil becerilerini geliştirici nitelikte olduğu elde edilen bulgular arasındadır. Her sayının ilk bölümünde çeşitli resimlerle kelime ve kavram öğretimi yapılmaktadır. Örneğin; 4. sayıda yaprak, kozalak, çiçek ve meyve resimleri verilerek "Ağaçlarla ilgili bu şeylerin adını bakalım biliyor musunuz?" diye sorulmuş ve çocuklardan cevap vermeleri istenmiştir. Kavram öğretimi 3. sayıdan itibaren yoğunlaşmıştır. Örneğin; 14. sayıda mevsimler ve aylar anlatılırken "Sonbaharın üç ayı eylül, ekim, kasımdır. Sonbaharın bir adı da 'güz'dür. Sonra kış başlar. Aralık, ocak, şubat. Kış biter, ilkbahar gelir. Mart, nisan, mayıs. Haziran, temmuz, ağustos yaz aylarıdır." ifadeleri kullanılmıştır. Bunlarla birlikte her sayıda resimli öykü bulunmaktadır; ikinci sayıdan itibaren "Tüytop Ormanda" adıyla devam eden bu öykülerde resimlerle kavram öğretimi yapılmaktadır.

Popüler bilimin manasına uygun olarak incelenen dergilerde bilimsel konuların gündelik dille ve eğlenceli bir şekilde anlatıldığı görülmektedir. Örneğin; 3. sayıda "Kardan adamlar kış bitince nereye gidiyorlar? Yaz uykusuna mı yatıyorlar?" şeklinde eğlenceli bir dil ile kış mevsimi anlatılıı̧tır. 13. sayıda 
da deniz altındaki dünyanın anlatıldığı bölümde şnorkel ağzında olan çocuk annesine "Tömöm önnö" diye cevap vermiş̧ir. Bu ifadenin doğrusu parantez içinde "Tamam anne" şeklinde gösterilmiştir.

Ele alınan konuların bilimsel bilgiler ile tutarlı olduğu dergide akıcı bir dil kullanıldığı, dil bilgisi kurallarına genellikle uyulduğu; ancak yazım kurallarına çoğunlukla uyulmadığı, bu konuda gerekli özenin gösterilmediği anlaşılmaktadır. Noktalama yanlışlıkları genellikle tırnak işareti ve üç nokta kullanımının hatalı olmasından kaynaklanmaktadır. Örneğin; 1. sayıda "Şu zavallı karıncaya yardım edeyim de kurtulsun," ifadesinde tırnak içinde nokta yerine virgül kullanıımıştır. 15. sayıda da "Şimdi şu dallarda elmalar, armutlar, kayısılar, erikler olsaydı... Bir güzel karnımı doyursaydım..." ile başlayan kısımda üç noktaların kullanımı yanlıştır. Ayrıca, 5. sayıda "Afrika'da Hayvanlar Arasında" adlı çizgi öyküde "Az önce neredeyse bulutlara değecektim. şimdi bir ırmağın kıyısındayım..." ifadelerinde hem cümleye küçük harf ile başlanmış hem de üç nokta yanlış kullanıımıştır. Yine aynı öykünün devamında "Vay canına. bunlar timsah olmalı." ifadesinde cümleye küçük harfle başlanmıştır. Bunlara ek olarak 1. sayının 22. sayfasında ayrı yazılması gereken "sağ ol" ve 4. sayının 18. sayfasında "su samuru" ifadeleri birleşik yazılmıştır. Ayrıca, 9. sayının 15. sayfasında "yakan top" yerine "yakartop" yazıımıştır.

Anlatım, genel olarak dile yönelik duyarlııık kazandırma yönelimindedir. Ancak; 9. sayının 18. sayfasında kız ismi olarak kullanılan "Lena" ve 5. sayının 16. sayfasında yer alan "Tonya" ismi Türkçeye uygun değildir.

Dergi, genel olarak bilimsel düşünmeyi destekleyici yöndedir. Çocukların bilimsel düşünmesi deneylerle ve bulmacalarla sağlanmıştır. Dergilerde ele alınan konuların bilimle toplum arasında bağ kurduğu, toplumun her kesimi tarafından anlaşılabilir nitelikte olduğu ve öğrencilerin merakını uyandırdığı görülmektedir. Dergilerde çeşitli sorularla çocuklarda merak uyandırılmaktadır. Örneğin; 7. sayının 10. sayfasında kuşlar ile ilgili bölümde "Neymiş bakalım bu ortak özellikler?" sorusuyla çocukların merakı arttııımıştır. Ayrıca, dergilerde bulunan öykülerde genellikle soru ifadeleri kullanılmıştır.

\section{Tartışma ve Sonuç}

Mini Kumbara Dergisi'nin ilk 4 yıl içinde yayınlanan 16 sayısının biçimsel ve içeriksel özelliklerinin incelendiği bu araştırmanın sonuçları, derginin, büyük ölçüde yeterli olduğunu göstermektedir. TÜBITAK Çocuk Kitaplığı Dizisindeki kitapların iç yapı ve dış yapı özelliklerinin incelendiği Demircan (2006) tarafından yapılan bir çalışmanın sonuçları da ilgili kitapların, bir çocuk kitabında olması gereken iç yapı ve dış yapı ölçütlerini taşıdığını; iç yapı ve dış yapı ölçütlerini saptamakta kullanılan 75 maddeden 64 tanesinin 'yeterli' olduğunu göstermektedir.

Elde edilen veriler incelendiğinde içeriğin toplumsal ve kültürel konulara genel olarak dikkat çektiği, işlenen konuların öğrencilerin seviyesine uygun olduğu ve gelecekteki ihtiyaçlarına cevap verir 
nitelikte olduğu söylenebilir. Buna paralel olarak Güran Yiğitbaşı (2014) TRT Çocuk Dergisi'nin, çocuklara olumlu davranışlar kazandırma, kendi kültürel değerlerinin farkındalığını yaratma ve bunları çocukların eğlenceli zaman geçirmelerini sağlayarak gerçekleştirme amacı güttüğü sonucuna ulaşmıştır. Aynı şekilde Gönen, Katrancı, Uygun ve Uçuş (2011), çocuk kitaplarında yer alan mesajların çoğunlukla sosyal ve kültürel yapı, ahlaki öğütler ve toplumsal kurallar ile ilgili olduğunu belirlemişlerdir.

Ayrıca bulgularda yer alan bilgiler ele alınan konuların ilgi çekici ve gerçek yaşam temelli olduğunu göstermektedir. Buna ek olarak dergide yer verilen konuların öğrencilere yeni ve farklı deneyimler kazandırdığı ve amaçların öğrencilerin imkânları ile gerçekleşebilecek düzeyde olduğu sonuçlar arasındadır. Dergiler genel olarak değerlendirildiğinde öğrenme ihtiyaçlarını gidermekte ve öğrenmeyi teşvik etmektedir; fakat öğrencileri üst düzey düşünme becerilerini geliştirmeye yöneltmemektedir. Bu durum, derginin okul öncesi dönemdeki çocuklara yönelik olduğu düşünülürse olumsuz olarak değerlendirilmemelidir.

Araştırmada incelenen dergilerde dil ve üslubun öğrencinin seviyesine uygun olduğu ve yeni kavram ile kelimeleri öğretici olduğu; ayrıca dil becerilerini geliştirici nitelikte olduğu elde edilen sonuçlardandır. Aynı şekilde Demiryürek (2012) TRT Çocuk Dergisi'nde üslup, dil ve anlatım üzerinde titizlikle durulduğunu; derginin son sayılarına doğru Türkçenin zengin anlatım olanaklarına daha fazla yer verildiğini belirtmiştir. Ayrıca; Gönen, Katrancı, Uygun ve Uçuş (2011) tarafından yapılan çalışmada çocuk kitaplarının anlatım ve üslup açısından yüksek oranda sade-akıı bir dille yazıldığı ve neredeyse tamamında kurallı cümle yapısı kullanıldığı tespit edilmiştir.

Mini Kumbara Dergisi biçimsel özellikler açısından incelendiğinde metinlerde kullanılan görsellerin metnin içeriği ile uyumlu, öğrencinin ilgisini çekecek nitelikte ve bilişsel gelişim düzeyine uygun olduğu görülmektedir. Metinlerde kullanılan resimler, çizimler ve fotoğrafların kısmen gerçeğe yakın olduğu söylenebilir. Buna paralel olarak Demiryürek (2012) dergilerin, resimler konusunda oldukça başarılı olduğunu; gerek resimlerin seçimi, gerekse sayfa düzeni içerisinde yerleştirilmesi konusunda titizlikle çalışıldığını tespit etmiştir. Ulutaş ve Çaydaş (2013), ileri Yavrutürk dergilerinde yer alan teknoloji konulu resimlerin çocuklarda düş, düşlem ve düşünme gücünü geliştirme açısından oldukça önemli olduğu sonucuna ulaşmıştır.

Mini Kumbara Dergisi'nin içeriğinde bulunan görsellerde yer alan araç - gereçler bilimsel bilgilerle tutarlıdır. Ulutaş ve Çaydaş (2013), çalışmalarında dergide insanların yaşamlarını kolaylaştıracak araç - gereçlere yer verildiği, insanların gerek günlük ihtiyaçları için gerekse yaşamlarını daha kolay hale getirmek için sürekli bir arayış içerisinde oldukları, teknolojik gelişmelerin yoğunlaştığı ve geliştirilen modern araçlarla insanlığın doğa şartlarına hükmedebildiği sonucuna ulaşmışlardır. 
Incelenen derginin hacim ve ağırlık bakımından kullanışlı olduğu söylenebilir; ancak derginin basımında kaliteli malzeme kullanılmadığı görülmektedir. Demiryürek'in (2012) çalışmasında da dergi kâğıdının cinsinin çocuklara pek uymadığı sonucuna ulaşılmıştır.

Metinlerin oluşturulmasında kullanılan yazı karakteri ve büyüklüğünün, cümlelerin uzunluğunun öğrencinin seviyesine uygun olduğu araştırma sonuçları arasındadır. Derginin basımında kullanılan renklerin metinler ve görseller açısından uyumlu olduğu, sayfaların görsel tasarım ilkelerine uygun olduğu ve sayfa yapısını algılamayı kolaylaştıracak nitelikte olduğu görülmektedir. İncelenen derginin kapağının kısmen sağlam ve dikkat çekici olduğu söylenebilir. Gönen, Katrancı, Uygun ve Uçuş (2011), çocuk kitaplarında büyük ölçüde karton kapak kullanıldığını tespit etmiştir.

Dergide seçilen konuların öğrencileri daha fazla araştırma yapmaya yönelttiği de ulaşılan sonuçlar arasında yer almaktadır.

Araştırma sonuçlarına dayanılarak şu önerilerde bulunulabilir:

1. Mini Kumbara Dergisi'nin baskı sayısı arttırılarak daha fazla kitleye ulaşması sağlanmalıdır.

2. Derginin tanıtımı yapılmalıdır.

3. Dergi, yazım ve noktalama bakımından daha dikkatli hazırlanmalıdır.

4. Derginin cildinde ve kapağında daha kaliteli malzeme kullanılmalıdır.

\section{Kaynaklar}

Demircan, C. (2006). TÜBiTAK Çocuk kitaplığı dizisindeki kitapların dış yapısal ve iç yapısal olarak incelenmesi. Mersin Üniversitesi Eğitim Fakültesi Dergisi, 2(1), 12 - 27.

Demirel, ş., Çeçen, M. A., Seven, S., Tozlu, N. ve Uludağ M. E. (2011). Edebî metinlerle çocuk edebiyatı. (Ş. Demirel). Ankara: Pegem.

Demiryürek, G. (2012). TRT Çocuk dergisi'nin yapısal özellikleri bakımından değerlendirilmesi. Kastamonu Eğitim Dergisi 20 (3), 1017 - 1034.

Ekiz, D. (2003). Eğitimde araştırma yöntem ve metodlarına giriş. Ankara: Anı.

Gönen, M., Katrancı, M., Uygun, M., Uçuş, Ş. (2011). Illköğretim birinci kademe öğrencilerine yönelik çocuk kitaplarının içerik, resimleme ve fiziksel özellikleri açııından incelenmesi. Eğitim ve Bilim, 36 (160), $250-$ 265.

Güleryüz, H. (2003). Yaratıcı çocuk edebiyatı. Ankara: Pegem.

Güran Yiğitbaşı, K. (2014). Türkiye'de çocuk dergiciliği: TRT Çocuk Dergisi örneği. Iğdır Üniversitesi Sosyal Bilimler Dergisi, 5, 37-56.

Oğuzkan, A. F. (2010). Çocuk edebiyatı. Ankara: Anı.

Sönmez, V. ve Alacapınar, F. G. (2011). örneklendirilmiş bilimsel araştırma yöntemleri. Ankara: Anı.

Şimşek, T. (2002). Çocuk edebiyatı. Ankara: Rengarenk.

Ulutaş, A., Çaydaş, A. (2013). ileri Yavrutürk dergisinin teknoloji açısından değerlendirilmesi. International Journal of Social Sience, 6 (3) $759-771$. 
Ungan, S. ve Yiğit, F. (2014). Geçmişten günümüze Türkiye'de süreli çocuk yayınları. Dil ve Edebiyat Eğitimi Dergisi, 10, 184-198.

URL-1 http://www.biltek.tubitak.gov.tr/bdergi/populerbilimyazarligi.pdf 15.05.2015 .

URL-2http://www.isbank.com.tr/TR/hakkimizda/kumbara-dergisi/mini-kumbara-dergisi/Sayfalar/minikumbara-dergisi.aspx 15.05.2015.

Yılar, Ö. ve Celepoğlu, A. (2007). Çocuk yayınları ve bu yayınlarda bulunması gereken temel unsurlar. Ed. Ö. Yılar ve L. Turan. Çocuk edebiyatı (ss. 39-61). Ankara: Pegem.

Yıldırım, A. ve Şimşek H. (2005). Sosyal bilimlerde nitel araştırma yöntemleri. Ankara: Seçkin. 